\title{
The influence of defoliation and nitrogen on the regrowth of Rhodes grass (Chloris gayana Kunth). 1. Dry-matter production and tillering
}

\author{
A. Dovrat ${ }^{1}$, J. G. P. Dirven ${ }^{2}$ and B. Deinum ${ }^{2}$ \\ 1 Department of Field and Vegetable Crops, Faculty of Agriculture, Hebrew Univer- \\ sity, Rehovot, Israel \\ 2 Department of Field Crops and Grassland Husbandry, Agricultural University, \\ Wageningen, the Netherlands
}

Received: 30 December 1970

\section{Summary}

In a pot experiment cv. 'Common' (flowering) and cv. 'Katambora' (non-flowering) of Rhodes grass were cut every 14 or 28 days and fertilized with a low $(1.43 \mathrm{meq} / 100 \mathrm{~g}$ soil) or high $(8.29 \mathrm{meq} / 100 \mathrm{~g}$ soil) level of $\mathrm{N}$ during a 56 -day period. The experiments were carried out in a temperature-controlled greenhouse $\left(35^{\circ} \mathrm{C}\right.$ day and $25^{\circ} \mathrm{C}$ night), supplemented with artificial illumination during the day.

Extending the cutting interval from 14 to 28 days considerably increased total shoot weight ; this effect being greater than that of raising the application of $\mathrm{N}$ from a low to a high level. The initial regrowth following the 28-day cutting was considerably slower than that following the 14-day cutting and it was slower at high $\mathrm{N}$ than at low $\mathrm{N}$. Root weight per pot of low-N plants was 31 and $23 \%$ higher than that of high-N plants at 14- and 28-day cutting intervals, respectively.

Plants cut at long intervals produced a slightly less average number of tillers, but each tiller was of considerably greater weight, than plants cut at short intervals. The application of high $\mathrm{N}$ generally increased the average number of harvested tillers but caused individual tillers to regrow less times than those receiving low $\mathbf{N}$ irrespective of whether the cultivar tended to flower or not. The lack of persistence of individual tillers following high $\mathrm{N}$ was usually compensated by the formation of a greater number of new tillers than in low $\mathrm{N}$.

\section{Introduction}

The manipulation of defoliation and $\mathrm{N}$ application for maximum production of subtropical grasses has been the objective of many investigations (Henzell, 1962; Humphreys, 1966). Strong linear yield responses to increasing rates of $\mathrm{N}$ were observed in a number of experiments with Rhodes grass (Oakes and Skov, 1962; Henzell, 1963; Brockington, 1964) and in particular under conditions of unlimited moisture supply (Dovrat, 1966). As has been found with other grass species long, as opposed to short intervals, between cuttings resulted in higher total dry-matter yields (Leshem, 1965). As a long term effect however, fertilization with high rates of $\mathrm{N}$ together with long inter- 
vals between cuttings was found to induce slow initial regrowth, to diminish persistence of the grass in late summer and autumn, and to lead to a decline in yield (Dovrat and Cohen, 1970).

In this paper data are presented on changes which occur in distribution of dry matter and tillering pattern following different defoliation treatments and different rates of $\mathrm{N}$ to Rhodes grass grown in pots. The chemical composition of the harvested material will be reported in another paper (Dovrat et al., in prep.).

\section{Experimental}

\section{Materials}

The Rhodes grass cultivars used were: 'Common', a semi-fine-leaved variety which flowers freely under 12-14 h daylength conditions, and 'Katambora', a fine-leaved variety which hardly flowers under the above photoperiod.

\section{Treatments}

Cutting was carried out every 14 or 28 days over a period of 56 days. Two $\mathrm{N}$-fertilizer levels were applied, denoted low $\mathrm{N}$ or high $\mathrm{N}$. A factorial design in randomized blocks with 5 replications was used.

Identical treatments were given in two separate experiments but initial age of seedlings differed. Experiment 1 lasted from 21 April until 16 June 1969 for which 80-day old seedlings of 'Common' and 'Katambora' were used. In Experiment 2, 140-day old seedlings of 'Common' were used and it lasted from 25 August until 20 October. During experiment 1 daylength and light intensity were on the increase, whereas during Experiment 2 they were on the decrease.

\section{Procedures}

Plastic pots were filled with $6.3 \mathrm{~kg}$ infertile sandy soil to which small amounts of $\mathrm{MgSO}_{4}$ and powdered lime were added. Seventeen seedlings, each having 1 or 2 tillers, were planted in every pot. The seedlings were cut to a height of $6 \mathrm{~cm}$ and were left to regrow.

The pots were placed on the bench of a temperature-controlled greenhouse at $35 \pm$ $2^{\circ} \mathrm{C}$ during the day and $25 \pm 2^{\circ} \mathrm{C}$ during the night. $400-\mathrm{W}$ high-pressure mercury lamps, Philips HPLR) provided additional illumination during $12 \mathrm{~h}$ of the day. The sum of natural and artificial light, measured $15 \mathrm{~cm}$ above the pots, increased from

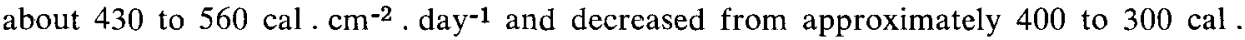
$\mathrm{cm}^{-2}$. day-1 total radiation during the course of Experiments 1 and 2, respectively. Two clippings were made before the start of the experiment to enhance tillering and to ensure good coverage of the pots. At this stage there were about 3 tillers per plant.

Five replicate pots of each treatment were placed in a $34 \times 112 \times 11 \mathrm{~cm}$ box. Sufficient pots and boxes were prepared to allow sampling one set at every clipping date. The boxes were lined with polyvinyl sheeting and were partly filled with water to wet the soil. The supply of water to the plants was through a small hole in the bottom of each pot. Water was frequently added to ensure a constant regime of near field capacity throughout the experimental period. To prevent salt damage pots were watered from above once a week. A basic nutrient solution containing $30 \mathrm{meq} \mathrm{KH}_{2} \mathrm{PO}_{4}, 5 \mathrm{meq} \mathrm{MgSO}_{4}$, $10 \mathrm{meq} \mathrm{Ca}\left(\mathrm{NO}_{3}\right)_{2}$ and $10 \mathrm{meq} \mathrm{KNO}_{3}$ was given per pot on the first and also on the 29 th day of the experimental period. Minor elements were also added at the first fertilization. The position on the bench of the boxes containing the pots was regularly 
changed so as to minimize position effects of the greenhouse.

The superimposed fertilizer treatments consisted of low $\mathrm{N}$ or high $\mathrm{N}$ equaling the application of 1 or 3 meq $N$ per g expected dry-matter production, respectively. Nitrogen, as ammonium-nitrate solution, was given to the 14-day clipping treatment immediately after each clipping. The low- $\mathrm{N}$ application was given to the 28 -day treatment immediately after clipping whereas the high $\mathrm{N}$ was given in two applications: the first immediately after clipping and the second some 14 days later. The total amounts of low $\mathrm{N}$ and high $\mathrm{N}$ were $90 \mathrm{meq} \mathrm{N} /$ pot $(1.43 \mathrm{mcq} / 100 \mathrm{~g}$ coil) and $522 \mathrm{meq} \mathrm{N} /$ pot $(8.29$ $\mathrm{meq} / 100 \mathrm{~g}$ soil), respectively.

Clipping was always to 6-cm stubble height and the number of vegetative and flowering tillers was recorded at each clipping. A tiller was considered flowering as soon as the inflorescence emerged from the leaf sheath.

A light-weight-plastic ring was placed (3-5 days after cutting) around the base of each regrowing tiller at the start of the experiment - referred to as 'original' tillers in two replicate pots of each treatment in Experiment 1. After each cutting a ring was added to each regrowing tiller so that at the end of the experiment the identification with regard to how many times original tillers regrew was ensured.

On every clipping date one set (i.e. five replicate pots of each treatment), was harvested for analysis. The contents were divided into the following three fractions: shoots, $6-\mathrm{cm}$ stubble and roots. The roots were carefully washed over a sieve to remove adhering soil and dead plant material. All fractions were immediately dried at $70^{\circ} \mathrm{C}$, weighed, ground and stored for chemical analysis (Dovrat et al., in prep.).

\section{Results}

Dry-matter production

Dry-matter production from shoot of both 'Common' and 'Katambora', is shown in Fig. 1. The mean total amount of shoot weight per pot following two 28-day growth periods was some $40 \%$ greater than that following four 14-day periods of regrowth. 'Katambora' was slightly more productive than 'Common', especially when cut every 28 days. Furthermore it can be noted that the yields of subsequent harvests were on the increase in Experiment 1 and on the decrease in Experiment 2. This may be associated with the quantity of light reaching the plants and with the daylength which were increasing in Experiment 1 and decreasing in Experiment 2.

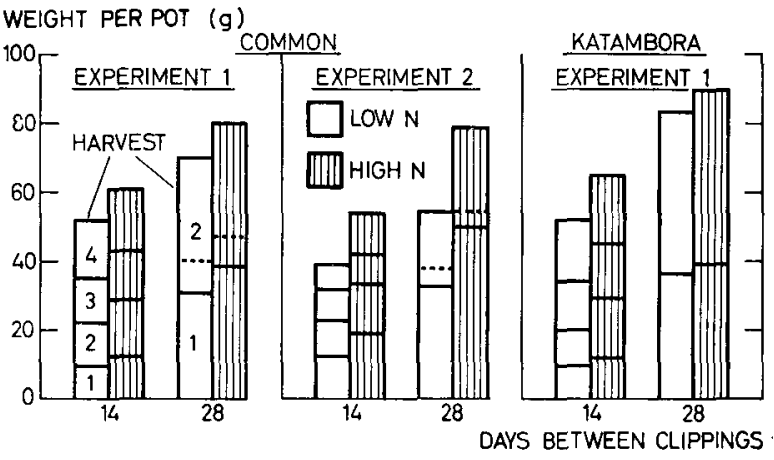

Fig. 1. The effect of cutting and nitrogen application on the produc. tion of shoot dry weight in 'Common' and 'Katambora' Rhodes grass. - . - Yield reached after 14 days in the 28-day clipping treatment. 
THE INFLUENCE OF DEFOLIATION AND NITROGEN ON THE REGROWTH OF RHODES GRASS. 1

Of particular interest is the difference in the amount of regrowth made during 14 days following a cutting interval of either 14 or 28 days (the dotted line in the 28-day columns of Fig. 1). It shows that the yield accumulated during 14 days following 2 cutlings at 14-day intervals was almost $60 \%$ greater than that following one cutting after 28 days.

With regard to the influence of $\mathrm{N}$ application it was found that the mean total shoot weight per pot increased $25 \%$ in 'Common' and 13\% in 'Katambora' following high $\mathrm{N}$ as compared with low $\mathbf{N}$. It can therefore be concluded that, when under these experimental conditions, the cutting interval is extended from 14 to 28 days, total shoot weight increases much more than when $\mathrm{N}$ application is raised from a low to a high level. Apparently the low $\mathrm{N}$ level applied was already rather high. Data from $6-\mathrm{cm}$ stubble weights showed insignificant differences between treatments.

Plants which were fertilized with high $\mathrm{N}$ produced less root dry weight than those given low amounts of $\mathrm{N}$, quite independently of cutting treatment (Fig. 2). Averaging the harvests of both experiments, root weights per pot of high- $\mathrm{N}$ plants were $31 \%$ and $23 \%$ less than of low-N plants in the 14 and 28-day clipping treatments, respectively. During the first 28-day period of growth the root weight of plants cut twice was similar to that of plants cut once as they received the same amount of $\mathrm{N}$ fertilizer. During the second 28-day period of growth, however cutting tended to interact with $\mathbf{N}$ level. In Experiment 1 high $N$ suppressed root weight less in plants cut once than when cut twice but this effect was not discernable in Experiment 2.

At each $\mathrm{N}$ level the trend of root-weight changes was quite similar in both experiments. At the low $\mathrm{N}$ level root weight increased until the 28th or 42 nd day and ceased to increase (Experiment 1) or even decreased (Experiment 2) afterwards. At the high $\mathrm{N}$ level however, no increase of root weight occurred until the 14th day following the start of the experiment.

The mean shoot/root ratio of high-N plants was found to be almost twice as great as that of low- $\mathrm{N}$ plants irrespective of cutting treatments. Root weights of 'Katambora' were not determined.

\section{Tillering}

The average number of tillers per harvest and per pot of 'Katambora' was greater that of 'Common' (Table 1).

The high $\mathrm{N}$ application compared with low $\mathrm{N}$ generally caused a marked increase in the number of tillers per harvest (more in 'Katambora' than in 'Common'), particular-

WEIGHT PER POT $(\mathrm{g})$

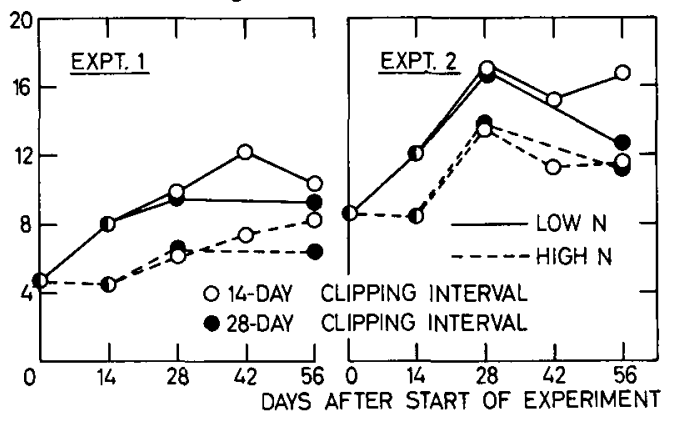

Fig. 2. The effect of cutting and nitrogen application on the production of root dry weight of 'Common' Rhodes grass. 
Table 1. The effect of cutting and nitrogen application on the number and mean weight of tillers (Experiment 1).

\begin{tabular}{|c|c|c|c|c|c|c|c|}
\hline \multirow{2}{*}{$\begin{array}{l}\text { Days } \\
\text { between } \\
\text { cuttings }\end{array}$} & \multirow{2}{*}{$\begin{array}{l}\text { Nitrogen } \\
\text { application }\end{array}$} & \multicolumn{5}{|c|}{ Number of harvested tillers per pot ${ }^{1}$} & \multirow{2}{*}{$\begin{array}{l}\text { Mean dry } \\
\text { weight } \\
\text { (mg/tiller) }\end{array}$} \\
\hline & & $5 . \mathrm{V}$ & $19 . \mathrm{V}$ & 2.VI & 16.VI & average & \\
\hline \multicolumn{8}{|c|}{ cv. 'Common' } \\
\hline \multirow[t]{2}{*}{14} & Low & 64 & 80 & $82(1)$ & $110(1)$ & 84 & 150 \\
\hline & High & 74 & 119 & $108(1)$ & $125(1)$ & 107 & 140 \\
\hline \multirow[t]{2}{*}{28} & Low & & $79(1)$ & & $119(2)$ & 99 & 350 \\
\hline & High & & $97(2)$ & & $98(6)$ & 98 & 410 \\
\hline \multicolumn{8}{|c|}{ cv. 'Katambora' } \\
\hline \multirow[t]{2}{*}{14} & Low & 86 & 150 & 121 & 149 & 127 & 100 \\
\hline & High & 103 & 188 & 147 & 149 & 147 & 110 \\
\hline \multirow[t]{2}{*}{28} & Low & & 118 & & 109 & 114 & 360 \\
\hline & High & & 159 & & 163 & 161 & 280 \\
\hline
\end{tabular}

1 Figures in brackets : number of flowering tillers.

ly during the first half of the experiment period. However, during the second half of the experiment less tillers were present in high $\mathrm{N}$ compared with low- $\mathrm{N}$ plants of " $\mathrm{Com}$ mon' when clipped after 28 days.

The effect of cutting interval on the number of tillers was less pronounced than that of nitrogen application in both 'Common' and 'Katambora'. Only a relatively sma!l decrease occurred in the number of tillers at each harvest of plants clipped every 28 days compared with plants clipped at 14-day intervals. On the other hand the mean tiller weight of 28-day clipped plants was more than twice higher than of 14-day clipped plants.

Very few tillers of 'Common' flowered when plants were cut evcry 14 days. If cut

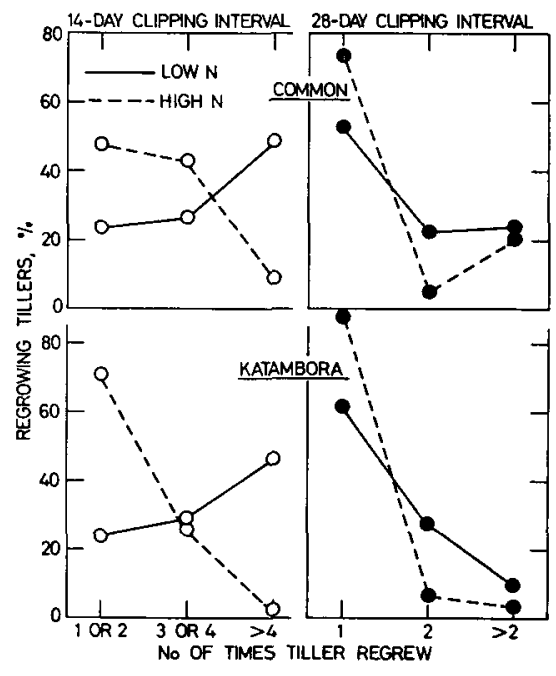

Fig. 3. The effect of cutting and nitrogen application on the number of times original tillers of 'Common' and 'Katambora' Rhodes grass regrow (percentage distribution). Data from Experiment 1. 
at 28-day intervals the high- $\mathrm{N}$ plants produced 2 to 3 times more flowering tillers than low-N plants. With this the percentage of flowering tillers never exceeded $6 \%$ of the total number of tillers. In 'Katambora' no flowering was observed.

The number of times the original tillers regrew was recorded and their percentage distribution is shown in Fig. 3.

When low-N plants were cut every 14 days (total of 4 cuttings) about half of the original tillers regrew at least 4 times. However, in the high- $\mathrm{N}$ application some $50 \%$ and $70 \%$ of the tillers regrew only once or twice in 'Common' and 'Katambora', respectively. The percentage of those regrowing more than 4 times decreased to $10 \%$ or less. Thus the application of high $\mathrm{N}$ caused tillers to persist less than plants given low applications of $\mathrm{N}$.

When plants were cut every 28 days (total of 2 cuttings) most of the original tillers of both cultivars only regrew once. As in the 14-day cutting interval here again high as opposed to low $\mathrm{N}$ caused a larger percentage of these tillers to regrow once only.

\section{Discussion}

\section{Cutting frequency}

Dry-matter production followed the usual pattern of increasing total shoot weight as the number of cuttings decreased. Since the relative increase was similar for both the flowering 'Common' and the non-flowering 'Katambora', the presence of a small number of flowering stems did not affect total shoot yield. Long intervals between cuttings caused a slight decrease in the average number of harvested tillers, however their individual weight was markedly increased (Table 1). Whether a causal relationship exists between tiller size and auxiliary bud development could not be ascertained.

The emergence of flowering stems in plants of 'Common' clipped every 14 days is hardly expected since under field conditions flowering stems generally do not appear before 12-14 days following cutting. The relatively high survival rate of tillers which were cut every 14 days at low $N$ (Fig. 3) suggests that at the time of cutting most of the growing apices or active meristematic tissues were below the $6-\mathrm{cm}$ cutting height. Consequently they retained their ability to regrow. The low survival rate of the original tillers at high $\mathbf{N}$ may indicate that most of the growing apices or active meristematic tiscues were above the $6-\mathrm{cm}$ cutting height. However, this assumption seems hardly plausible since the survival rate of tillers in the apparently non-flowering 'Katambora' was lower than in 'Common'.

The survival rate of original tillers from 28-day cut plants was less than half that of those cut every 14 days. A considerable number of 'Common' tillers failed to regrow in spite of the fact that only about $6 \%$ of them flowered. The removal of the growing apices or active meristems at the time of cutting may be a reason for this. That this, however, is not the only cause is evident from the similary low survival rate of tillers which were cut at 28 days in the apparently non-flowering 'Katambora'.

The interrelationship between cutting frequency and tillering, which has also been reported for temperate grasses (Davidson and Milthorpe, 1965), may explain the difference in the amount of regrowth made by plants which were cut after 14 or 28 days (Fig. 1). The initial growth rate per unit pot area following the 28-day cutting was considerably smaller than that of tillers following the 14-day cutting. This evidently was caused by the presence of a smaller number of regrowing tillers of the 28 compared with the 14-day cut plants. 


\section{Nitrogen}

The relative influence of $\mathrm{N}$ application on dry-matter production was much less than that of defoliation, except in the case of root weight. High $\mathrm{N}$ reduced root weight by approximately $30 \%$ compared with low $\mathrm{N}$ independently of cutting frequency. In pot experiments decreases in grass-root weights were obtained by Nielsen and Cunningham (1964) and many other workers. The results from field experiments are less conclusive. For example Garwood (1967) found a reduction in the root weight of a grass/clover sward with the increase of N supply. Holt and Fisher (1960), however, found no reduction in root weight under a sward of Coastal Bermudagrass when ammonium nitrate was applied up to very high levels. This was also true for root weights under a sward of Rhodes grass (Dovrat and Cohen, 1970).

It is a well established fact that increasing the supply of $\mathrm{N}$ almost always increases the shoot/root ratio. Although root growth is enhanced by an increase in $\mathrm{N}$ supply (but to a lesser extent than shoot growth) under conditions of severe $\mathrm{N}$ deficiency, once a moderate supply of $\mathrm{N}$ has been obtained, further increases often reduce root weight (Brouwer et al., 1961; Auda et al., 1966).

The average number of vegetative and flowering tillers at the time of harvest was generally greater in high $\mathrm{N}$ than in low $\mathrm{N}$. With this it should be noted that high $\mathrm{N}$ failed to produce more tillers than low $\mathrm{N}$ in 'Common' when cut at 28-day intervals during the second half of the experiment (Table 1). However, an important finding was that increasing $\mathrm{N}$ supply decreased the persistence of individual tillers irrespective of cutting interval. Sometimes the regrowth of certain tillers in high-N plants suddenly ceased 7-10 days following cutting. Thus the lack of persistence of individual tillers following high $\mathrm{N}$ was usually compensated by the formation of a greater number of new tillers than in low $\mathrm{N}$.

Furthermore the initial growth rate of tillers after cutting in 'Common' at 28-day intervals was lower in high $\mathrm{N}$ than in low $\mathrm{N}$. A similar observation was made by Alberda (unpublished) working with perennial ryegrass grown under conditions of unlimited moisture supply and high rates of $\mathrm{N}$ fertilization.

In conclusion it can be stated that the manipulation of defoliation and $\mathrm{N}$ application, in order to maintain maximum dry-matter production of Rhodes grass, requires due consideration of the physiological processes operative in the maintenance of tillers.

\section{Acknowledgments}

This work was carried out by the senior author during the tenure as a visiting research officer at the Department of Field Crops and Grassland Husbandry of the Agricultural University at Wageningen during 1969. Mr K. Wind rendered very able technical assistance. The authors are grateful to Prof. M. L. 't Hart, Head of the Department, for his encouragement, advice and the provision of facilities.

\section{References}

Auda, H., R. E. Blaser \& R. H. Brown, 1966. Tillering and carbohydrate contents of orchardgrass as influenced by environmental factors. Crop Sci. 6: 139-143.

Brockington, N. R., 1964. Fertilizer responses of Giant Rhodes grass (Chloris gayana Kunth) in Northern Rhodesia. Emp. J. exp. Agric. 32: 76-83.

Brouwer, R., P. J. Jenneskens \& G. J. Borggreve, 1961. Growth responses of shoots and roots to inter- 
ruptions of the nitrogen supply. Jaarb. Inst. biol. scheik. Onderz. LandbGew. p. 29-36.

Davidson, J. L. \& F. L. Milthorpe, 1965. Carbohydrate reserves in the regrowth of cocksfoot (Dactylis glomerata). J. Brit. Grassld Soc. 20: 15-18.

Dovrat, A., 1966. Responses of Rhodes grass and overseeded legumes to nitrogen and potash fertilizers and to the availability of soil potassium in Israel. Exp. Agric. 2: 255-263.

Dovrat, A. \& Y. Cohen, 1970. Regrowth potential of Rhodes grass (Chloris gayana Kunth) as affected by nitrogen and defoliation. Proc. 11th Int. Grassld Congr. p. 552-554.

Dovrat, A., B. Deinum \& J. G. P. Dirven, 1971. The influence of defoliation and nitrogen on the regrowth of Rhodes grass (Chloris gayana Kunth). II. Non-structural carbohydrate, total $\mathrm{N}$ and nitrate content. Neth. J. agric. Sci. (in preparation).

Garwood, E. A., 1967. Some effects of soil water conditions and soil temperature on the roots of grasses. I. The effect of irrigation on the weight of root material under various swards. $J . B r$. Grassld Soc. 22: 176-181.

Henzell, E. F., 1962. The use of nitrogen fertilizers on pastures in the sub-tropics and tropics. In: A review of nitrogen in the tropics with particular reference to pastures. Bull. Commonw. Bur. Pastures Field Crops 46: 161-172.

Henzell, E. F., 1963. Nitrogen fertilizer responses of pasture grasses in south-eastern Queensland. Aust. J. exp. Agric. Anim. Husb. 3: 290-299.

Holt, E. C. \& F. L. Fisher, 1960. Root development of Coastal Bermudagrass with high nitrogen fertilization. Agron. J. 52: 593-596.

Humphreys, L. R., 1966. Pasture defoliation practice: A review. J. Aust. Inst. agric. Sci. 32: 93-105.

Leshem, Y., 1965. Effect of height and frequency of cutting on yield and chemical composition of irrigated forage grasses. Proc. 9th Int. Grassld Congr. p. 1661-1665.

Nielsen, K. F. \& R. K. Cunningham, 1964. The effects of soil temperature and form and level of nitrogen on growth and chemical composition of Italian ryegrass. Proc. Soil Sci. Soc. Am. 28: 213-218.

Oakes, A. J. \& O. Skov, 1962. Responses of four pasture grasses to nitrogen in the dry tropics. Agron. J. 54 : 176-178. 